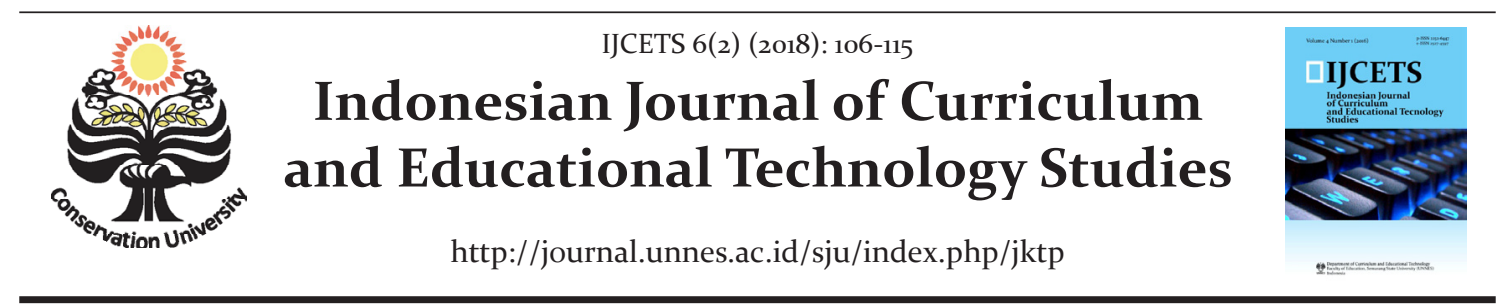

\title{
Benarkah Kompetensi Sosial Homeschooler Rendah?
}

\author{
Winda Falah Setianing Arum, ${ }^{\bowtie}$ Haryono, ${ }^{1}$ Istyarini ${ }^{1}$ \\ ${ }^{1}$ Fakultas Ilmu Pendidikan, Universitas Negeri Semarang, Semarang, Indonesia \\ DOI: https://doi.org/10.15294/ijcets.v6i2.21241
}

\section{Article History \\ Received : August 2018 Accepted : October 2018 Published : November 2018}

\section{Keywords}

Homeschooler; homeschooling; social competency; tutor visit learning program

\begin{abstract}
Abstrak
Penelitian ini bertujuan untuk mendeskripsikan kompetensi sosial homeschooler, program pembelajaran tutor visit di Ansa School Semarang, serta pengaruh antara program pembelajaran tersebut terhadap kompetensi sosial homeschooler. Penelitian yang dilakukan menggunakan metode penelitian kualitatif deskriptif, melibatkan empat homeschooler setara Sekolah Menengah Pertama (SMP) kelas VII dan VIII, serta beberapa narasumber terkait. Hasil penelitian menunjukkan bahwa kompetensi sosial yang dimiliki oleh keempat homeschooler cukup baik yang ditunjukkan dengan terpenuhinya beberapa indikator-indikator dalam penelitian serta keterbukaan mereka terhadap orang lain. Kemudian, program pembelajaran tutor visit yang diselenggarakan oleh Ansa School merupakan program pembelajaran yang sangat terstruktur dan sistematis dengan tujuan untuk memberikan fasilitas belajar bagi anak-anak yang memiliki kebutuhan khusus, sehingga program pembelajaran tutor visit dapat disimpulkan menjadi salah satu faktor pembentuk kompetensi sosial homeschooler.
\end{abstract}

\begin{abstract}
This study aims to describe the social competence of homeschoolers, learning tutors visit program at ANSA School Semarang, and the influence of the learning program on the social competence of homeschoolers. The research was conducted using descriptive qualitative research method involving four homeschoolers equivalent to Junior High School (SMP) grades VII and VIII and some relevant resources. The results show that the social competence of the four homeschoolers is good enough according to some indicators in this resarch, for instance their openness to others. Moreover, the learning tutor visit program organized by ANSA School is a highly structured and systematic learning program with the aim to provide learning facilities for children who have special need, so the learning program visit tutor could be categorize to be one of the homeschooler competency forming factors.
\end{abstract}

$凶$ Corresponding author :

Address: Jurusan Kurikulum dan Teknologi Pendidikan,

Fakultas Ilmu Pendidikan, UNNES Semarang 50229

E-mail: windafalah86@gmail.com (c) 2018 Universitas Negeri Semarang p-ISSN 2252-6447 e-ISSN 2527-4597 


\section{PENDAHULUAN}

Pada era modern seperti sekarang, pendidikan berkembang dengan sangat pesat. Selain pendidikan formal seperti di sekolah yang mewajibkan setiap peserta didik untuk datang dan belajar sesuai dengan waktu yang di tentukan, kini anak lebih bisa memilih sendiri konsep sekolah yang mereka inginkan dengan mengikuti pendidikan alternatif sebagai upayanya.

Munculnya beragam pendidikan alternatif ini selain dapat memberikan pilihan kepada anak sebagai peserta didik, juga menjadi salah satu faktor yang dapat dipertimbangkan oleh orang tua dalam memilih pendidikan yang tepat bagi anak. Selain dilatar belakangi oleh perkembangan zaman, munculnya pendidikan alternatif juga tidak dapat terlepas dari gaya hidup masyarakat yang semakin modern dan pola pikir yang berkembang luas untuk menilai bahwa pendidikan tidak hanya bisa dilakukan dengan cara yang terkesan kuno dan monoton. Pendidikan alternatif juga merupakan respons atas pendidikan persekolahan (schooling system) yang kaku dan cenderung tidak dapat mengakomodasi keragaman kebutuhan siswa (Muniroh, 2009; Rahardjo, 2018).

Pada saat ini, banyak ragam pendidikan alternatif yang mengusung berbagai macam tema dalam pembelajaran. Aron (2003) misalnya mengidentifikasi beberapa jenis pendidikan alternatif di Amerika Serika (A.S.) dilihat dari target populasi, tujuan, tempat penyelenggaraan, relasinya dengan sekolah formal, sumber dana, dan sertifikasinya. Purnamasari et al. (2017) juga mengidentifikasi beberapa jenis pelaksanaan homeschooling di Indonesia, antara lain yang dominan yaitu homeschooling berbasis kultur dan komunitas.

Penyelenggaraan pendidikan alternatif yang pada saat ini telah dipayungi dengan undang-undang serta peraturan yang jelas (Undang-Undang No. 20 Tahun 2003 tentang Sistem Pendidikan Nasional pasal 27), menjadi daya tarik sendiri terhadap masyarakat khususnya masyarakat perkotaan. Salah satu pendidikan alternatif yang diselenggarakan di berbagai macam kota besar di Indonesia adalah homeschooling atau dikenal dengan sekolah rumah.

Homeschooling merupakan pendidikan alternatif di luar sekolah atau dapat disebut juga sebagai pendidikan informal terstruktur dengan keluarga sebagai penanggung jawab utama dan berorientasi kepada kemampuan belajar alamiy- ah anak untuk meningkatkan kecerdasan serta memaksimalkan potensi yang dimiliki oleh peserta didik. Jika dibandingkan dengan sekolah formal, homeschooling tentu memiliki segudang kelebihan dalam penyelenggaraannya, selain mata pelajaran serta waktu belajar yang dapat disesuaikan dengan bakat, minat, serta kegiatan lain para siswa, homeschooling juga memberikan pilihan metode dan program pembelajaran yang cukup beragam serta tidak monoton. Sehingga para siswa lebih menikmati kegiatan belajar mereka (Sumardiono, 2018).

Dengan berbagai keunggulan tersebut, wajar jika banyak orang tua tertarik dengan penyelenggaraan homeschooling. Kekhawatiran orang tua terhadap maraknya bullying, pergaulan bebas, tawuran antar pelajar, dan kenakalan siswa lainnya dirasa tidak terjadi jika anak-anak mereka bersekolah di homeschooling. Pada homeschooling orang tua mempunyai peran penting dan bertanggung jawab penuh atas pembelajaran yang di lakukan oleh anak-anak mereka, hingga dapat lebih diarahkan sesuai dengan visi keluarga yang bersangkutan (lihat misal Masripah, 2008; Wahyudi, 2018; dan Fajar, 2018).

Selain permasalahan tersebut, adanya permasalahan lain di pendidikan formal seperti kurikulum yang kaku dan kurang akomodatif pada keunikan siswa, serta kebijakan pendidikan pada sekolah formal yang berubah-ubah, tidak akan berbengaruh terhadap para peserta homeschooling. Dengan konsep pembelajaran yang menyenangkan, mata pelajaran serta waktu belajar yang disepakati oleh peserta didik, orang tua, serta tutor, meminimalisir adanya tekanan atau stres yang dialami peserta didik. Selain itu, peserta didik juga dituntut untuk menjadi individu mandiri dan bertanggung jawab terhadap keputusan yang mereka ambil (Sumardiono, 2018).

Adanya nilai tambah yang dimiliki oleh homeschooling, masih diiringi dengan ragamnya permasalahan yang timbul sebagai dampak negatif dari penyelenggaraannya. Pandangan masyarakat mengenai sekolah berembel-embel "kejar paket" menjadi salah satu nilai minus terhadap kemampuan diri seorang individu. Masyarakat awam menganggap bahwa kejar paket ini mencerminkan peserta didik yang tertinggal bahkan tidak dapat mengikuti pembelajaran formal di sekolah, misalnya para peserta didik yang cenderung lambat dalam berfikir, tidak naik kelas, tidak dapat beradaptasi dengan lingkungan, putus sekolah, dan lain-lain. 
Masalah lain dari adanya homeschooling adalah pandangan masyarakat awam mengenai rendahnya kompetensi sosial para siswa homeschooling atau biasa disebut dengan homeschooler (Sumardiono, 2018, pp. 46-51). Tentu saja hal tersebut menjadi salah satu yang harus diperhatikan apabila orang tua memilih homeschooling bagi anak mereka mengingat manusia diciptakan sebagai makhluk sosial yang tentu saja dalam hidupnya memerlukan peran dari orang lain bahkan sejak dalam kandungan sampai dengan akhir hidupnya. Apabila seorang individu tidak pandai dalam bersosialisasi tentu selama hidupnya mereka akan mengalami kesulitan.

Anggapan mengenai rendahnya kompetensi sosial para homeschooler wajar terjadi mengingat homeschooling sering dipahami aktivitas belajar anak di rumah saja, sehingga akses yang tidak cukup luas untuk berinteraksi dengan teman sebaya, lingkungan hidup, bahkan masyarakat di sekitar mereka, tetangga dekat misalnya. Pergaulan serta komunikasi mereka dianggap sebatas dengan orang tua atau keluarga dan dengan tutor sehingga terdapat kemungkinan homeschooling mencetak pribadi yang introvert atau tertutup. Walau hal ini sudah dibantah oleh para praktisi homeschooling (misal Sumardiono, 2018, pp. 46-51), namun agaknya karena sosialisasi yang kurang menjadikan anggapan masyarakat awam tersebut masih tetap muncul hingga sekarang.

Dalam pelaksanaan homeschooling yang diselenggarakan oleh lembaga tertentu-tidak sepenuhnya oleh keluarga-peran orang tua dan tutor yang sangat berpengaruh terhadap perkembangan anak. Pada pendidikan seperti homeschooling anak berkembang di bawah dorongan dari orang tua serta perhatian dari tutor. Apabila anak kurang diperhatikan, serta kurang diberi dorongan untuk bergaul baik oleh orang tua atau oleh tutor, maka bisa jadi anak tidak menyadari bahwa berinteraksi dengan teman sebaya merupakan hal yang penting dalam hidupnya. Masyarakat awam relatif menganggap bahwa berbeda halnya jika anak belajar di sekolah formal. Meskipun tanpa dorongan dari orang tua, anak dapat dengan sendirinya bergaul dan berinteraksi dengan orang lain khususnya teman sebayanya. Bahkan anakpun mulai bisa memilih dengan individu seperti apa mereka akan berteman.

Sebuah riset di Amerika Serikat oleh Mayberry et al. (1995) menunjukkan bahwa 92\% pengawas sekolah sendiri menganggap bahwa anak-anak homeschooler tidak memperoleh pengalaman sosialisasi yang cukup. Penelitian Setiawati \& Suparno (2010) mengafirmasi hal tersebut, bahwa interaksi sosial anak-anak homeschooler dengan teman sebaya kurang berkembang dibandingkan anak-anak sekolah reguler, karena anak-anak homeschooler lebih banyak berinteraksi dengan keluarganya sendiri dan orang-orang yang lebih tua usianya. Kemampuan kerjasama anak-anak homeschooler juga kurang, karena kesempatan mengembangkan kemampuan tersebut (misal: mengemukakan pendapat, menyelesaikan perbedaan dalam kelompok) memang kurang.

Namun tentu saja penelitian tersebut memiliki konteks tertentu. Penelitian Wijayarto \& Haryanto (2015) justru menunjukkan hal sebaliknya, yaitu kompetensi anak-anak homeschooler yang mereka teliti lebih tinggi dibandingkan anak-anak sekolah pada umumnya. Selain itu penelitian Purnamasari et al. (2017) juga menunjukkan banyak nilai-nilai positif yang ditanamkam dalam homeschooling, antara lain kemandirian, juga menjadikan keluarga memperhatikan betul-betul visi pendidikan anak-anaknya. Dengan demikian, dapat dikatakan bahwa kompetensi sosial anak-anak homeschooler bervariasi. Patut diduga bahwa konsep, sistem, materi, dan praktik belajar homeschooling yang beragam memengaruhi keragaman kompetensi sosial anak-anak homeschooler.

Selebihnya, penelitian mengenai homeschooling banyak fokus pada pola belajar dan dimensi tata kelola. Herfinaly \& Aryani (2013) menunjukkan bahwa anak-anak homeschooler yang belajar menggunakan model pendidikan jarak jauh belajar berinteraksi sosial secara asosiatif maupun disosiatif dalam bentuk mengimitasi idola yang dilihat di media dan sugesti dari orang-orang di sekitarnya. Lebih lanjut, penelitian Imaniyah et al. (2016) mengidentifikasi pola hubungan pengelolaan lembaga homeschooling dengan masyarakat, antara lain melalui perencanaan yang matang, komunikasi dioptimalkan menggunakan berbagai media, evaluasi secara rutin, dan pelibatan orang tua dalam kegiatan outbond dan sejenisnya.

Beberapa penelitian tersebut cukup memberikan gambaran bahwa kompetensi sosial anak-anak homeschooler memang beragam. Hal tersebut perlu ditindaklanjuti dengan mengidentifikasi hal-hal apa saja yang menyebabkan keragaman kompetensi sosial anak-anak homeschooler? Dalam hal ini satu fokus yang menarik dan penting dikaji adalah program untuk 
pengembangan kompetensi sosial homeschooler. Di antara penyelenggara homeschooling, baik oleh keluarga maupun lembaga tertentu tentu perlu dicari perbedaannya, karena kemungkinan besar akan diperoleh hasil yang berbeda. Namun dalam hal ini peneliti akan fokus terlebih dulu pada penyelenggara homeschooling oleh lembaga pendidikan tertentu.

Berdasarkan penelusuran informasi awal oleh peneliti pada hari Senin 27 Februari 2017 pada salah satu penyelenggara homeschooling di kota Semarang, Pusat Kegiatan Belajar Masyarakat (PKBM) Anugerah Bangsa atau lebih dikenal dengan Ansa School, adanya anggapan bahwa rendahnya kompetensi sosial pada homeschooler dibenarkan. Namun hal tersebut tidak sematamata terjadi dengan sendirinya, terdapat banyak faktor yang menjadi sebab munculnya anggapan tersebut. Walau begitu, seiring dengan kekhawatiran mengenai potensi rendahnya kompetensi sosial anak homeschooler, pihak Ansa School mengembangkan program tutor visit.

Salah satu upaya yang dilakukan untuk meminimalisasi adanya anggapan tersebut adalah membuka kegiatan ekstrakurikuler dengan tujuan untuk meningkatkan kompetensi sosial siswa terutama dengan teman sebaya. Upayaupaya yang telah di laksanakan bukan berarti tanpa ada suatu hambatan. Kegiatan tetap diadakan, namun pihak Ansa School menyadari bahwa tidak semua siswa dapat mengikutinya. Masih terdapat siswa yang tidak bisa mengikuti kegiatan-kegiatan ekstrakurikuler dan layanan bimbingan konseling yang diselenggarakan karena adanya berbagai macam faktor.

Selain kesibukan lain yang dimiliki oleh siswa terutama siswa yang mengikuti program pembelajaran tutor visit, belum adanya kesadaran pada diri siswa tentang pentingnya berinteraksi sosial dengan sesama teman menyebabkan siswa malas datang pada kegiatan ekstrakurikuler tersebut. Artikel penelitian ini menggambarkan pelaksanaan program tutor visit oleh Ansa School dan mengidentifikasi apakah anak-anak homeschooler benar-benar rendah kompetensi sosialnya? Hasil penelitian ini dengan demikian berkontribusi memperluas wawasan mengenai praktik homeschooling sebagai bagian dari pendidikan alternatif di Indonesia.

\section{METODE}

Penelitian ini menggunakan pendekatan kualitatif untuk memberikan gambaran atau penegasan mengenai kompetensi sosial homeschooler yang mengikuti program pembelaja- ran tutor visit, bagaimana proses pembelajaran yang dilaksanakan pada program pembelajaran tutor visit, serta berapa besar program pembelajaran tersebut mempengaruhi kompetensi sosial yang dimiliki oleh para homeschooler.

Penelitian ini dilaksanakan selama kurang lebih 2 bulan yaitu antara bulan September awal sampai dengan akhir Oktober 2017 di Yayasan Anugerah Bangsa (Ansa) School, Semarang. Sumber data dalam penelitian terdiri dari data primer yang bersumber dari informan-informan terkait, seperti Pihak Yayasan, Kepala Sekolah, Wali Kelas, Koordinator Tutor visit, Tutor, Homeschooler (empat homeschooler dipilih dalam penelitian ini sebagai contoh subjek penelitian), serta Orang Tua. Sedangkan data sekunder yang mendukung penelitian diambil melalui analisis dokumen-dokumen pendukung seperti kurikulum, dan lain-lain.

Teknik pengumpulan data yang dilakukan dalam penelitian ini menggunakan observasi, wawancara, serta dokumentasi. Ketiga terknik tersebut saling berkesinambngan dan melengkapi satu sama lain. Teknik analisis data yang digunakan dalam penelitian ini adalah metode analisis data kualitatif menurut Miles dan $\mathrm{Hu}-$ berman (Emzir, 2011, pp. 129-135) yaitu (1) reduksi data, (2) data display, (3) penarikan/verifikasi kesimpulan. Sementara itu untuk menguji keabsahan data menggunakan tiga teknik menurut Sugiyono (2012, p. 363), yaitu (1) perpanjang pengamatan, (2) triangulasi, dan (3) analisis kasus negatif.

\section{HASIL DAN PEMBAHASAN}

Tujuan penelitian ini adalah mendeskripsikan bagaimana kompetensi sosial homeschooler yang mengikuti program pembelajaran tutor visit serta bagaimana proses pembelajaran pada program tersebut. Selain itu, penelitian juga dilakukan untuk menjawab pertanyaan peneliti mengenai berapa besar pengaruh program pembelajaran tutor visit terhadap kompetensi sosial homeschooler mengingat sudah banyak upayaupaya yang dilakukan oleh Ansa School untuk meminimalisir terjadinya sikap introvert pada siswa yang mengikuti program pembelajaran tutor visit.

\section{A. Kompetensi Sosial Homeschooler}

Analisis kompetensi sosial didasarkan pada teori kecerdasan sosial dari Daniel Gole- 
man. Pada teori tersebut Goleman (2015, p. 101) membagi kecerdasan sosial menjadi dua unsur atau kategori besar, yaitu (1) kesadaran sosial yang merujuk pada bagaimana individu merasakan batiniah orang lain sampai dengan memahami perasaan serta pikirannya dan (2) fasilitas sosial yang merujuk pada bagaimana seorang merasakan apa yang orang lain rasa atau memikirkan apa yang orang lain pikirkan.

Penulis beranggapan bahwa apabila individu memiliki kecerdasan sosial yang baik, tentu kompetensi atau kemampuan sosial yang dimiliki juga baik namun jika kompetensi sosialnya baik, belum tentu dapat dikategorikan memiliki kecerdasan sosial. Setelah melaksanakan penelitian, penulis menemukan fakta bahwa kompetensi sosial yang dimiliki oleh keempat homeschooler-yang menjadi subjek penelitian ini-dapat dikatakan cukup baik. Hal tersebut ditunjukkan dengan terpenuhinya beberapa indikator dalam penelitian serta keterbukaan mereka terhadap orang lain, meskipun salah satu dari mereka terdapat anak yang cenderung introvert, tetapi bukan berarti anak tersebut tidak mau berhubungan dengan orang lain sama sakali.

Meskipun beberapa indikator dalam kecerdasan sosial terpenuhi, belum menjadikan mereka dikategorikan cerdas secara sosial. Karena indikator-indikator yang telah mereka miliki belum konsisten ada di setiap momen sosial yang mereka alami. Seperti contohnya indikator dalam aspek presentasi-diri pada komponen fasilitas sosial, yaitu kemampuan mengendalikan diri yang menurut pengamatan serta menurut keterangan orang tua hal tersebut terkadang mampu mereka lakukan namun terkadang juga tidak mampu mereka lakukan. Berikut penuturan selengakapnya dari narasumber orang tua.

"Anak-anak usia ini (SMP, antara 11 sampai dengan 13 tahun) kan masih labil ya. Jadi terkadang dia mampu mengendalikan diri dengan baik namun terkadang juga tidak." (W.OT1.1-25.10.17)

Kompetensi atau kemampuan sosial merupakan aspek yang kompleks pada diri manusia, maka hal tersebut juga berlaku bagi keempat homeschooler. Terdapat berbagai macam faktor yang mempengaruhi, sehingga menjadikan mereka memiliki kompetensi sosial yang cukup baik saat ini. Selain karena dukungan dari keluarga serta lingkungan sekitar, aspek yang paling mempengaruhi kompetensi sosial mereka adalah aspek internal yang ada dalam diri mereka untuk mau berinteraksi atau berhubungan den- gan orang lain.

Jika dilihat dari sudut pandang mereka sebagai homeschooler, adanya anggapan bahwa homeschooler merupakan anak-anak yang anti sosial sangat tidak dibenarkan. Meskipun memiliki interaksi atau hubungan sosial yang minim, namun mereka tidak digolongkan sebagai anak-anak yang anti sosial atau individualis. Hal tersebut tentu dibuktikan dengan keaktifan mereka untuk mau berinteraksi atau bersosial dengan semua orang di lingkungan sekitarnya, baik di rumah maupun di yayasan. Seperti penjelasan dari narasumber orang tua berikut.

"Najwa ketika di lingkungan baru lebih memilih untuk menjadi pengamat terlebih dahulu. Tetapi bukan berarti dia orang yang introvert atau menutup diri. Karena dia memiliki energi yang besar maka dia lebih suka bermain dengan laki-laki dan permainannya pun yang menggunakan tenaga seperti bermain sepeda atau bermain bola. Meskipun di lingkungan sekitar dia tidak mempunyai teman sebaya, tetapi dia tetap bermain dengan anak-anak yang usianya lebih kecil atau lebih besar. Biasanya dia lebih suka dengan yang lebih kecil karena dia suka menjadi pemimpin. Dan tentu saja dia selalu saya arahkan untuk bersosialisasi. Karena manusia kan makhluk sosial." (W.OT2.1-16.10.17)

Hal tersebut sejalan dengan pernyataan Saputra (2007, p. 91) bahwa homeschooler kurang bersosialisasi adalah salah satu mitos yang berkembang di masyarakat. Bersosialisasi merupakan suatu kegiatan interaksi dengan individu lain, tidak harus dengan sebaya tetapi semua usia. Homeschooler diajarkan untuk dapat menempatkan diri di lingkungan manapun dengan siapapun dan menjalin hubungan bukan karena paksaan namun karena kesadaran bahwa hubungan antar manusia itu penting.

Berdasarkan pernyataan tersebut, penulis juga menyimpulkan masing-masing homeschooler memiliki kesadaran bahwa interaksi atau hubungan sosial merupakan hal yang penting. Selain itu, karena aspek sosial merupakan salah satu aspek perkembangan, maka hal tersebut tentu akan selalu ada dalam diri individu dan tidak akan pernah lepas. Oleh karena itu, pada usia mereka yang baru menginjak masa awal remaja yaitu 11 sampai dengan 13 tahun, kompetensi atau kemampuan sosial akan terus berkembang dan mungkin akan jauh lebih baik seiring dengan berjalannya waktu.

Melihat homeschooler yang saat ini berada dalam rentang usia antara 11 sampai dengan 
13 tahun, tentu tidak dapat terlepas dari masalah pencarian jati diri dalam diri mereka. Hal tersebut terbukti terjadi pada keempat homeschooler yang diamati. Pada usia ini mereka mulai memasuki lingkungan sosial yang baru dan lebih luas. Selain itu mereka juga selalu ingin menunjukkan bahwa mereka adalah individu yang benar, bisa menjadi panutan, serta dapat dipercaya oleh orang lain.

Mengacu pada teori psikososial yang diungkapkan oleh Erikson (dalam Desmita, 2008, pp. 43-44) homeschooler objek penelitian ini berada dalam masa adolescent, yakni masa yang berlangsung selama masa-masa remaja. Pada tahap ini anak dihadapkan kepada pencarian jati diri mereka. Mulai merasakan sesuatu perasaan tentang identitasnya sendiri. Perasaan bahwa ia adalah individu yang unik dan siap untuk memasuki suatu peran dalam masyarakat baik bersifat menyesuaikan atau memperbaharui. Pada masa ini merupakan masa yang sulit karena adanya peralihan antara masa kanak-kanak dan masa dewasa.

Selain itu adanya kepekaan terhadap perubahan sosial dan historis pada pihak lain, oleh sebab itu anak akan mengalami krisis identitas. Bila krisis tersebut tidak segera diatasi, maka anak akan mengalami kebingungan peran atau kekacauan identitas yang berakibat pada anak merasa terisolasi, cemas, hampa, dan bimbang.

Homescooler yang berada dalam masa adolesence tentu membutuhkan arahan serta bimbingan dari lingkungan, baik lingkungan keluarga maupun lingkungan pergaulan yang lebih luas. Berdasarkan hasil penelitian, para orang tua dari masing-masing homeschooler begitu menyadari akan hal tersebut. Orang tua mereka memahami bagaimana karakter anak pada masa remaja, sehingga para orang tua tidak hanya memberikan kepercayaan, dan tanggung jawab penuh namun juga memberikan motivasi serta arahan agar mereka tidak salah dalam bergaul.

Hal baiknya, anak-anak tersebut menempuh pendidikan dengan cara homeschooling, sehingga orang tua dapat sedikit lega karena mereka juga ikut andil dalam pergaulan sosial yang dimiliki oleh anak-anak mereka sehingga minim kemungkinan anak-anak tersebut terjerumus ke dalam pergaulan negatif. Orang tua masing-masing homeschooler juga begitu memahami bahwa apa yang terjadi pada masa ini akan mempengaruhi masa berikutnya.

Jika kebanyakan orang beranggapan bahwa homeschooling mencetak pribadi yang introvert atau tertutup akan dunia luar (misal Setiawati \& Suparno, 2010), hal tersebut tidak ditemukan oleh penulis selama penelitian. Kembali penulis tekankan bahwa kompetensi sosial yang dimiliki oleh individu memiliki latar belakang atau berbagai faktor yang mempengaruhi dan cukup kompleks. Sehingga seorang individu menjadi introvert atau tidak itu bergantung pada pilihannya masing-masing. Karena hal paling mendasar dari interaksi atau hubungan sosial yang melandasi kompetensi sosial berasal dari dalam masing-masing individu.

Berdasarkan hasil penelitian ini, keempat homeschooler justru memiliki interaksi atau hubungan sosial yang beragam. Mereka tidak hanya bergaul dengan teman sebaya saja melainkan dengan orang yang lebih muda atau bahkan lebih tua usianya dari mereka. Oleh karena itu, penulis telah sampaikan pada awal pembahasan bahwa kompetensi sosial yang mereka miliki cukup baik pada saat ini.

Hal tersebut sejalan dengan pernyataan Revaldi (2010, p. 108) yang menyebutkan bahwa anak homeschooling biasanya lebih matang secara sosial karena mereka terbiasa berkomunikasi dan berinteraksi dengan orang-orang dari beragam usia. Tidak sebatas dengan teman sebaya, tetapi ragam usia sebagaimana realitas di tempat kerja dan masyarakat.

\section{B. Program Pembelajaran Tutor Visit}

Program pembelajaran tutor visit termasuk kedalam program pembelajaran distance learning atau program pembelajaran jarak jauh dengan metode pembelajaran homeschooling. Pembelajaran homeschooling diartikan oleh Ansa School sebagai pembelajaran yang dilaksanakan di rumah homeschooler dengan mendatangkan guru atau tutor dan bertujuan untuk memberikan fasilitas belajar terhadap peserta didik yang membutuhkan perlakuan khusus.

Hal tersebut sejalan dengan pernyataan Satmoko (2016, p. 52) yang menegaskan bahwa homeschooling atau dalam istilah lain disebut home education atau home based learning merupakan penyelenggaraan pendidikan yang dilakukan secara mandiri di dalam lingkungan keluarga. Pelaksanaannya didasarkan pada tanggung jawab sebagai orang tua dalam memenuhi hak anak untuk kebutuhan memperoleh pendidikan. Namun, meski dimaknai sebagai pendidikan berbasis rumah, proses penyelenggaraan 
homeschooling dapat dilakukan di lokasi atau tempat yang disesuaikan dengan kebutuhan anak, seperti lembaga pelatihan, tempat kursus, ataupun dimana saja dengan sarana apa saja.

Program pembelajaran tutor visit merupakan salah satu bentuk pendidikan alternatif yang tergolong dalam pendidikan nonformal. Dengan demikian pelaksanaannya dilindungi oleh Undang-Undang No. 20 Tahun 2003 tentang Sistem Pendidikan Nasional.

Hal tersebut sejalan dengan penjelasan Mulyadi (2007, p. 19) bahwa persekolahan di rumah dilindungi oleh undang-undang yaitu dalam Undang-Undang Nomor 20 Tahun 2003 tentang Sistem Pendidikan Nasional (Sisdiknas), dalam Pasal 27 Ayat (1) dikatakan: "Kegiatan pendidikan informal yang dilakukan oleh keluarga dan lingkungan berbentuk kegiatan secara mandiri." Lalu pada Ayat (2) dikatakan bahwa: "Hasil pendidikan sebagaimana dimaksud dalam ayat (1) diakui sama dengan pendidikan formal dan nonformal setelah peserta didik lulus ujian sesuai dengan standar nasional pendidikan.”

Selain didasari oleh undang-undang yang jelas, program pembelajaran tutor visit yang dilaksanakan oleh Ansa School juga disusun berdasarkan delapan standar nasional pendidikan yaitu Standar Kompetensi Lulusan, Standar Isi, Standar Proses, Standar Pendidikan dan Tenaga Kependidikan, Standar Sarana dan Prasarana, Standar Pengelolaan, Standar Pembiayaan, kemudian Standar Penilaian. Namun sedikit berbeda pada standar proses, karena pendidikan nonformal sehingga sifatnya lebih fleksibel.

Pada pelaksanaannya program pembelajaran tutor visit merupakan salah satu bentuk dari homeschooling tunggal. Karena kegiatan belajar mengajar yang dilakukan bersifat mandiri dengan satu tutor mengampu satu homeschooler saja, sehingga kegiatan belajar mengajar yang berlangsung lebih menyerupai dengan les privat.

Jika dilihat dari sudut pandang penyelenggaraan homeschooling sebagai salah satu program pembelajaran dalam lingkup pendidikan nonformal, maka pelaksanaannya dinilai baik karena telah terstruktur dan sistematis. Ditandai dengan tujuan program yang jelas, yaitu memberikan fasilitas belajar terhadap peserta didik dengan kebutuhan khusus yang tidak dapat mengikuti pembelajaran formal bahkan pembelajaran komunitas di yayasan. Sasaran yang tepat, jenis kegiatan, dasar pelaksanaan yang je- las, proses pelaksanaan kegiatan yang sistematis mulai dari perencanaan sampai dengan evaluasi pembelajaran, waktu belajar yang telah terukur dan disesuaikan, fasilitas yang memadai, serta biaya yang telah diperkirakan.

Beberapa kelebihan program pembelajaran tutor visit yang dilaksanakan oleh Ansa sebagai berikut.

Pertama, program pembelejaran tutor visit dilaksanakan secara privat dengan satu tutor mengampu satu homeschooler. Oleh karena itu, kegiatan belajar mengajar yang berlangsung tentu lebih fokus. Selain itu, program pembelajaran tutor visit juga bersifat fleksibel yang berarti dapat disesuaikan dengan waktu belajar, gaya belajar, serta kemampuan homeschooler. Oleh karena itu, jelas jika setiap homeschooler memiliki perbedaan dalam kegiatan belajar mengajar yang dilaksanakan setiap pertemuannya.

Kedua, pada pelaksanaannya yang bersifat sangat fleksibel, sehingga memungkinkan bagi homeschooler untuk mencari atau mengembangkan potensi yang dimilikinya. Oleh karena itu, mayoritas dari homeschooler di Ansa School merupakan anak-anak dengan kebutuhan khusus. Dalam hal ini bukan hanya berkebutuhan khusus dalam arti memiliki kekurangan saja, namun berkebutuhan khusus dalam arti memiliki kelebihan atau prestasi lain di luar akademik yang tidak memungkinkan bagi mereka untuk menempuh pendidikan secara formal di sekolah.

Ketiga, program pembelajaran tutor visit yang dilaksanakan oleh Ansa School terakreditasi oleh Dinas Pendidikan terkait, serta berinduk pada yayasan Ansa School yang merupakan salah satu penyelenggara PKBM. Dengan demikian, para peserta didik bahkan calon peserta didik tidak perlu mengkhawatirkan ijazah yang diperoleh, karena ijazah tersebut dapat digunakan untuk melanjutkan pada jenjang pendidikan berikutnya.

Keempat, tutor yang mengampu pembelajaran dalam kegiatan belajar mengajar merupakan tutor pilihan yang dapat menyesuaikan gaya belajar masing-masing homeschooler. Tutor dalam pelaksanaan kegiatan belajar mengajar pada program pembelajaran tutor visit tidak hanya bertugas untuk menyampaikan materi pembelajaran saja. Namun juga bertanggung jawab dalam perkembangan homeschooler. Terlebih lagi, tutor sudah terbiasa dengan pernyataan atau pemikiran yang out of the box dari setiap homeschooler. Dengan demikian dapat disim- 
pulkan bahwa tutor di Ansa School khususnya yang mengampu dalam program pembelajaran tutor visit dapat digolongkan tutor yang cerdas.

Beberapa kelemahan program pembelajaran tutor visit yang dilaksanakan oleh Ansa sebagai berikut.

Pertama, yang menjadi kelemahan program tutor visit adalah meskipun program pembelajaran tutor visi berinduk pada PKBM yang tentu saja kurikulum juga disamakan dengan pembelajaran komunitas yang diselenggarakan di PKBM. Program pembelajaran tutor visit ini belum memiliki dokumen Silabus serta rencana pelaksanaan pembelajaran (RPP) khusus untuk penyelenggaraan program pembelajarannya, sehingga kegiatan belajar mengajar yang berlangsung menggunakan Silabus serta RPP yang sama dengan program pembelajaran komunitas.

Semestinya, Silabus dan RPP dirancang khusus untuk program pembelajaran tutor visit. Hal terbut dikarenakan jenis pelaksanaan yang berbeda antara program pembelajaran tutor visit dengan program pembelajaran komunitas.

Kedua, meskipun dalam penyelenggaraan program pembelajaran tutor visit ini tutor yang dipilih merupakan tutor-tutor dengan kualitas yang tinggi, namun masih terdapat beberapa tutor lintas bidang. Pengaruh hal tersebut terhadap kegiatan belajar mengajar yang dilaksanakan adalah kurang maksimalnya tutor dalam menyampaikan materi pelajaran. Telah disebutkan bahwa tutor merupakan ujung tombak pelaksana kegiatan yang bertugas tidak hanya memberikan materi namun juga membimbing. Jika dalam tugas memberikan materi terdapat beberapa kekurangan maka tutor tidak dapat dinilai sebagai ahli dalam bidang tersebut.

\section{Pengaruh Tutor Visit terhadap Kompe- tensi Sosial Homeschooler}

Meskipun hubungan atau interaksi sosial mereka cenderung minim, namun tidak berarti mereka tidak berinteraksi sama sekali dengan dunia luar. Diketahui bahwa keempat homeschooler tersebut pernah menempuh jenjang pendidikan formal, sehingga mereka tentu memahami bagaimana berinteraksi atau berhubungan dengan orang lain.

Bahkan mereka cenderung lebih baik ketika berinteraksi dengan orang lain. Hal tersebut ditunjukkan dengan komunikasi mereka yang baik, perlakuan mereka terhadap orang lain yang memiliki kekurangan juga baik, kejujuran dalam diri mereka, sikap apa adanya yang selalu ditampilkan ketika berhubungan atau berinteraksi dengan orang lain, dan lain sebagainya.

Hal tersebut sejalan dengan hasil penelitian Wijayarto \& Haryanto (2015, p. 32) yang membandingkan kompetensi sosial antara siswa homeschooling dengan siswa reguler sekolah dasar didapatkan nilai mean untuk homeschooling sebesar 73,36 dan nilai mean untuk sekolah reguler sebesar 6o,43. Dengan perbedaan nilai mean tersebut dapat disimpulkan bahwa kompetensi sosial siswa homeschooling lebih tinggi jika dibandingkan dengan kompetensi sosial siswa reguler sekolah dasar.

Wali kelas saat diwawancara mengenai kompetensi sosial homeschooler menyampaikan hal berikut.

"Apa yang telah Saudara lihat, seperti anakanak yang terbuka dengan adanya orang lain, memiliki sopan santun, dan dapat berinteraksi dengan baik, sebenarnya itu bisa dibilang anak-anak yang "sudah jadi" dalam arti mereka sudah melalui pembimbingan dari pihak kami serta pihak-pihak yang bersangkutan seperti orang tua serta keluarga. Sebetulnya mereka disini pun tidak bebas sekali, tetap ada atauran-aturan yang harus mereka ikuti." (W.WK.2-26.10.17)

Berdasarkan penuturan narasumber tersebut, jelas jika kompetensi sosial yang mereka miliki pada saat ini tentu tidak diperoleh dengan sendirinya. Tentu terdapat banyak campur tangan orang-orang yang ada di sekeliling mereka seperti orang tua dan keluarga, orang-orang di lingkungan sekitar mereka, tutor pembimbing serta pihak yayasan Ansa School yang secara sadar membenarkan bahwa hubungan atau interaksi sosial merupakan hal penting.

Hal tersebut sejalan dengan pernyataan dari Revaldi (2010, p. 109) bahwa problem sosial pada anak homeschooling merupakan titik perhatian dari homeschooling sebagai strategi untuk menghindari kekhawatiran orang tua, masyarakat, dan anak agar tidak teraliensi dari lingkungan. Sebagai satu kekhawatiran masyarakat luas, maka keluarga, komunitas, maupun organissi penyelenggara homeschooling hendaknya dapat merancang program yang tepat hingga kompetensi sosial anka-anak homeschooler dapat berkembang optimal.

\section{SIMPULAN}

Berdasarkan pada temuan di lapangan, kompetensi sosial yang dimiliki oleh homeschooler cukup baik. Para homeschooler me- 
rupakan anak-anak yang sadar akan pentingnya interaksi sosial antar manusia ditunjukkan dengan keterbukaan mereka dalam berhubungan dengan orang lain (di luar keluarga), namun tidak memungkiri masih terdapat beberapa homeschooler yang memiliki karakter introvert sehingga terkesan menutup diri dari lingkungan sosialnya. Namun tentu hal ini tidak dapat langsung disimpulkan disebabkan oleh karena ia belajar di Ansa School. Selain itu, meskipun secara kesuluran peserta didik baik yang mengikuti program pembelajaran tutor visit maupun tidak, memiliki kompetensi sosial yang baik, bukan berarti saat ini mereka memiliki kecerdasan sosial yang baik pula.

Program pembelajaran tutor visit merupakan salah satu jenis program pembelajaran yang menggunakan metode homeschooling. Dengan metode pembelajaran homeschooling tersebut, peserta didik dapat belajar di rumah sendiri dengan lebih fokus dan tanpa mengganggu kegiatan lain yang mereka miliki. Program pembelajaran tutor visit yang diselenggarakan oleh Ansa School hadir untuk memberikan solusi bagi peserta didik yang tidak mampu untuk mengikuti pembelajaran di sekolah formal. Tidak mampu dalam hal ini adalah anak-anak yang memiliki kebutuhan khusus. Kebutuhan khusus diartikan sebagai anak-anak yang tidak hanya memiliki kekurangan saja tetapi anak-anak yang memiliki potensi lebih misalnya atlet, model, penyanyi, pembalap, dan lain sebagainya.

Pengaruh atau dampak program pembelajaran tutor visit terhadap homeschooler adalah homeschooler dengan karakter yang tertutup atau introvert dapat mulai belajar untuk berhubungan atau berinteraksi dengan orang lain yang bukan anggota keluarga mereka melalui program pembelajaran tutor visit ini. Interaksi tersebut adalah dengan tutor-tutor yang ditugaskan oleh pihak Ansa School untuk memberikan materi pelajaran kepada homeschooler. Dampak atau pengaruh lain dari adanya program pembelajaran tutor visit yang diselenggarakan ini adalah kesadaran pada masing-masing individu akan pentingnya pembelajaran. Dalam hal ini tidak ada homeschooler yang terpaksa mengikuti pembelajaran, mereka mengikutinya dengan sadar bahwa kegiatan belajar mengajar yang dilakukan merupakan kegiatan yang penting dan memberikan dampak positif terhadap diri mereka.

\section{DAFTAR PUSTAKA}

Aron, L.Y. (2003). Toward a Typology of Alternative Education Programs: a Compilation of Elements from the Literature. Washington, D.C.: Urban Institute.

Desmita. (2008). Psikologi Perkembangan. Bandung: Remaja Rosdakarya.

Emzir. (2011). Metode Penelitian Kualitatif: Analisis Data. Jakarta: RajaGrafindo Persada.

Fajar, A.N.F. (2018). Motivasi Orang Tua Memilih Homeschooling (Studi Kasus pada Orang Tua Muslim yang Menyekolahkan Anak di Community Based Education Kota Salatiga tahun 2018). Skripsi. Salatiga: Institut Agama Islam Negeri Salatiga.

Goleman, D. (2015). Social Intelligence: Ilmu Baru tentang Hubungan Antar-Manusia. Jakarta: Gramedia Pustaka Utama.

Herfinaly, R. \& Aryani, L. (2013). Interaksi Remaja yang Bersekolah di Homeschooling dengan Menggunakan Metode Distance Learning. Jurnal Psikologi, 9(1), 40-47.

Imaniyah, R.I., Sutopo, H., \& Zulkarnain, W. (2016). Pengelolaan Hubungan Sekolah dan Masyarakat Home-schooling. Manajemen dan Supervisi Pendidikan, 1(1), 67-73.

Masripah, I. (2008). Motivasi Orang Tua dalam Menyelenggarakan Sistem Pendidikan Sekolah Rumah bagi Pendidikan Anak Usia Dini di Komunitas Belajar Homeschooling: Rumah Kerlip Bandung. Jurnal Administrasi Pendidikan, $8(2), 73-87$.

Mayberry, M., Knowles, J.G., Ray, B., \& Marlow, S. (1995). Home Schooling: Parents Educators. Thousand Oaks, CA: Corwin Press.

Moleong, L.J. (2010). Metodologi Penelitian Kualitatif. Bandung: Remaja Rosdakarya.

Mulyadi, S. (2007). Homeschooling: Rumah Kelasku, Dunia Sekolahku. Jakarta: Penerbit Buku Kompas.

Muniroh, S.M. (2009). Homeschooling, Alternatif Pendidikan Humanistik (Studi Kasus Pembelajaran pada Pendidikan Alternatif Qaryah Thayyibah Kalibening, Salatiga, Jawa Tengah. Forum Tarbiyah, 7(1), 115-130.

Pemerintah Republik Indonesia. (2003). UndangUndang Nomor 20 Tahun 2003 Tentang sistem Pendidikan Nasional. Jakarta.

Purnamasari, I., Suyata, \& Dwiningrum, S.I.A. (2017). Homeschooling dalam Masyarakat: Studi Etnografi Pendidikan. Jurnal Pembangunan Pendidikan: Fondasi dan Aplikasi, 5(1), 14-31.

Rahardjo, T. (2018). Sekolah Biasa Saja. Yogyakarta: InsistPress.

Revaldi, A. (2010). Memilih Sekolah untuk Anak. Jakarta: Inti Medina.

Saputra, A. (2007). Rumahku Sekolahku. Yogyakarta: Graha Pustaka. 
W.F.S. Arum et al./Indonesian Journal of Curriculum and Educational Technology Studies 6(2) (2018): 106-115

Satmoko, R. (2016). Buku Pintas Sekolah Alternatif. Jakarta: Pedar Kindy.

Setiawati, E. \& Suparno. (2010). Interaksi Sosial dengan Teman Sebaya pada Anak Homeschooling dan Anak Sekolah Reguler (Studi DeskriptifKomparatif). Indigenous, 12(1), 55-65.

Sudjana, D. (2006). Evaluasi Pendidikan Luar Sekolah: untuk Pendidikan Nonformal dan Pengemban gan Sumber Daya Manusia. Bandung: Remaja Rosdakarya.

Sugiyono. (2012). Metode Penelitian Pendidikan (Pendekatan Kuantitatif, Kulitatif dan RED). Bandung: Alfabeta.
Sumardiono, A. (2018). 55 Prinsip E Gagasan Homeschooling. Bogor \& Jakarta: Halaman Muka Publishing.

Wahyudi, A.D. (2018). Analisis Motivasi Orang Tua Memilih Homeschooling. Skripsi. Yogyakarta: Universitas Sanata Dharma.

Wijayarto, B. \& Haryanto. (2015). Perbandingan Kompetensi Sosial Siswa Komunitas Homeschooling dengan Siswa Reguler SD Muhammadiyah 1 Surakarta. Jurnal Prima Edukasia, 3(1), 26-32. 